Organisation de Coopération et de Développement Economiques

Organisation for Economic Co-operation and Development

24-Mar-2003

ENVIRONMENT DIRECTORATE

English - Or. English

JOINT MEETING OF THE CHEMICALS COMMITTEE AND

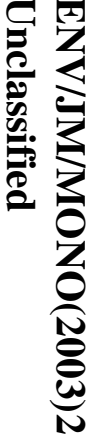

THE WORKING PARTY ON CHEMICALS, PESTICIDES AND BIOTECHNOLOGY

OECD SERIES ON TESTING AND ASSESSMENT

Number 40

DETAILED REVIEW DOCUMENT ON CLASSIFICATION IN OECD MEMBER COUNTRIES OF SUBSTANCES AND MIXTURES WHICH CAUSE RESPIRATORY TRACT IRRITATION AND CORROSION 
OECD Environment, Health and Safety Publications

Series on Testing and Assessment

No. 40

\title{
DETAILED REVIEW DOCUMENT ON CLASSIFICATION IN OECD MEMBER COUNTRIES OF SUBSTANCES AND MIXTURES WHICH CAUSE RESPIRATORY TRACT IRRITATION AND CORROSION
}

\author{
Environment Directorate \\ Organisation for Economic Co-operation and Development
}

March 2003 


\section{ALSO PUBLISHED IN THE SERIES ON TESTING AND ASSESSMENT:}

No. 1, Guidance Document for the Development of OECD

Guidelines for Testing of Chemicals (1993; reformatted 1995)

No. 2, Detailed Review Paper on Biodegradability Testing (1995)

No. 3, Guidance Document for Aquatic Effects Assessment (1995)

No. 4, Report of the OECD Workshop on Environmental Hazard/Risk Assessment (1995)

No. 5, Report of the SETAC/OECD Workshop on Avian Toxicity Testing (1996)

No. 6, Report of the Final Ring-test of the Daphnia magna Reproduction Test (1997)

No. 7, Guidance Document on Direct Phototransformation of Chemicals in Water (1997)

No. 8, Report of the OECD Workshop on Sharing Information about New Industrial Chemicals Assessment (1997)

No.9, Guidance Document for the Conduct of Studies of Occupational Exposure to Pesticides during Agricultural Application (1997)

No. 10, Report of the OECD Workshop on Statistical Analysis of Aquatic Toxicity Data (1998)

No. 11, Detailed Review Paper on Aquatic Testing Methods for Pesticides and industrial Chemicals (1998)

No. 12, Detailed Review Document on Classification Systems for Germ Cell Mutagenicity in OECD Member Countries (1998)

No. 13, Detailed Review Document on Classification Systems for Sensitising Substances in OECD Member Countries 1998)

No. 14, Detailed Review Document on Classification Systems for Eye Irritation/Corrosion in OECD Member Countries (1998)

No. 15, Detailed Review Document on Classification Systems for Reproductive Toxicity in OECD Member Countries (1998)

No. 16, Detailed Review Document on Classification Systems for Skin Irritation/Corrosion in OECD Member Countries (1998) 
No. 17, Environmental Exposure Assessment Strategies for Existing Industrial Chemicals in OECD Member Countries (1999)

No. 18, Report of the OECD Workshop on Improving the Use of Monitoring Data in the Exposure Assessment of Industrial Chemicals (2000)

No. 19, Draft Guidance Document on the Recognition, Assessment and Use of Clinical Signs as Humane Endpoints for Experimental Animals used in Safety Evaluation (1999)

No. 20, Revised Draft Guidance Document for Neurotoxicity Testing (in preparation)

No. 21, Detailed Review Paper: Appraisal of Test Methods for Sex Hormone Disrupting Chemicals (2000)

No. 22, Guidance Document for the Performance of Out-door Monolith Lysimeter Studies (2000)

No. 23, Guidance Document on Aquatic Toxicity Testing of Difficult Substances and Mixtures (2000)

No. 24, Guidance Document on Acute Oral Toxicity Testing(2001)

No. 25, Detailed Review Document on Hazard Classification Systems for Specifics Target Organ Systemic Toxicity Repeated Exposure in OECD Member Countries (2001)

No. 26, Revised Analysis of Responses Received from Member Countries to the Questionnaire on Regulatory Acute Toxicity Data Needs (2001)

No 27, Guidance Document on the use of the Harmonised System for the Classification of Chemicals which are Hazardous for the Aquatic Environment (2001)

No 28, Guidance Document for the Conduct of Skin Absorption Studies (in preparation)

No 29, Draft Guidance Document on Transformation/ Dissolution of Metals and Metal Compounds in Aqueous Media (2001)

No 30, Detailed Review Document on Hazard Classification Systems for Mixtures (2001)

No 31, Detailed Review Paper on Non-Genotoxic Carcinogens Detection: The Performance of In-Vitro Cell Transformation Assays (in preparation) 
No. 32, Guidance Notes for Analysis and Evaluation of RepeatDose Toxicity Studies (2000)

No.33, Harmonised Integrated Classification System for Human Health and Environmental Hazards of Chemical Substances and Mixtures (2001)

No. 34, Guidance Document on the Development, Validation and Regulatory Acceptance of New and Updated Internationally Acceptable Test Methods in Hazard Assessment (in preparation)

No. 35, Guidance notes for analysis and evaluation of chronic toxicity and carcinogenicity studies (2002)

No. 36, Report of the OECD/UNEP Workshop on the use of Multimedia Models for estimating overall Environmental Presistence and long range Transport in the context of PBTS/POPS Assessment (2002)

No. 37, Detailed Review Document on Classification Systems for Substances Which Pose an Aspiration Hazard (2002)

No. 38, Detailed Background Review of the Uterotrophic Assay Summary of the Available Literature in Support of the Project of the OECD Task Force on Endocrine Disrupters Testing and Assessment (EDTA) to Standardise and Validate the Uterotrophic Assay (2003)

No. 39, Guidance Document on Acute Inhalation Toxicity Testing (in preparation)

(c) OECD 2003

Applications for permission to reproduce or translate all or part of this material should be made to:Head of Publications Service, OECD, 2 rue André-Pascal, 75775 Paris Cedex 16, France 


\section{ABOUT THE OECD}

The Organisation for Economic Co-operation and Development (OECD) is an intergovernmental organisation in which representatives of 30 industrialised countries in North America, Europe and the Pacific, as well as the European Commission, meet to co-ordinate and harmonise policies, discuss issues of mutual concern, and work together to respond to international problems. Most of the OECD's work is carried out by more than 200 specialised Committees and subsidiary groups composed of Member country delegates. Observers from several countries with special status at the OECD, and from interested international organisations, attend many of the OECD's Workshops and other meetings. Committees and subsidiary groups are served by the OECD Secretariat, located in Paris, France, which is organised into Directorates and Divisions.

The work of the OECD related to chemical safety is carried out in the Environment, Health and Safety Programme. As part of its work on chemical testing, the OECD has issued several Council Decisions and Recommendations (the former legally binding on member countries), as well as numerous Guidance Documents and technical reports. The best known of these publications, the OECD Test Guidelines, is a collection of methods used to assess the hazards of chemicals and of chemical preparations. These methods cover tests for physical and chemical properties, effects on human health and wildlife, and accumulation and degradation in the environment. The OECD Test Guidelines are recognised world-wide as the standard reference tool for chemical testing.

More information about the Environment, Health and Safety Programme and its publications (including the Test Guidelines) is available on the OECD's World Wide Web site http://www.oecd.org/ehs/.

The Environment, Health and Safety Programme co-operates closely with other international organisations. This document was produced within the framework of the Inter-Organisation Programme for the Sound Management of Chemicals (IOMC).

The Inter-Organization Programme for the Sound Management of Chemicals (IOMC) was established in 1995 by UNEP, ILO, FAO, WHO, UNIDO and the OECD (the Participating Organisations), following recommendations made by the 1992 UN Conference on Environment and Development to strengthen co-operation and increase international co-ordination in the field of chemical safety. UNITAR joined the IOMC in 1997 to become the seventh Participating Organisation. The purpose of the IOMC is to promote co-ordination of the policies and activities pursued by the Participating Organisations, jointly or separately, to achieve the sound management of chemicals in relation to human health and the environment. 
This publication is available electronically, at no charge.

For the complete text of this and many other Environment, Health and Safety publications, consult the OECD's

World Wide Web site

(http://www.oecd.org/EN/document/0,EN-document-519-14-no-21-1080-0,00.html)

or contact:

OECD Environment Directorate,

Environment, Health and Safety Division

2 rue André-Pascal

75775 Paris Cedex 16

France

Fax: (33-1) 45241675

E-mail: ehscont@oecd.org 


\section{DETAILED REVIEW DOCUMENT ON CLASSIFICATION IN OECD MEMBER COUNTRIES OF SUBSTANCES AND MIXTURES WHICH CAUSE RESPIRATORY TRACT IRRITATION AND CORROSION}

\section{SCOPE AND DEFINITIONS}

\section{Scope}

1. This endpoint covers substances [and preparations] that cause irritation of the upper respiratory tract in humans.

\section{DESCRIPTION OF THE CLASSIFICATION SYSTEMS IN PLACE}

\section{The EU system (including Slovenia):}

2. The development of the R phrase, R37, Irritating to respiratory system within the EU is detailed in Appendix 1. The current criteria are as follows:

R 37: Irritating to respiratory system:

Is assigned to substances and preparations which cause serious irritation to the respiratory system based on:

a) practical observation in humans

b) positive results from appropriate animal tests

Comments regarding the use of R37:

In interpreting practical observations in humans, care should be taken to distinguish between effects which lead to classification with $\mathrm{R} 48^{(1)}$ from those leading to classification with R37. Conditions normally leading to classification with R37 are reversible and usually limited to the upper airways.

Positive results from appropriate animal tests ${ }^{(2)}$ may include data obtained in a general toxicity test, including histopathological data from the respiratory system. Data from the measurement of experimental bradypnea ${ }^{(3)}$ may also be used to assess airway irritation.'

${ }^{(1)} R 48=$ Danger of serious damage after repeated or prolonged exposure.

${ }^{(2)}$ Appropriate animal tests could include an acute inhalation toxicity study, a repeated-exposure inhalation study.

${ }^{(3)}$ The 'Alarie assay'.

3. As a general observation, historically, for Existing Substances the data that were used as a basis for classification with R37 were mainly based on human experience. However, in recent years there has been an increasing reliance on the use of information from animal studies. For New Substances, it is highly unlikely that there will be human experience information, hence classification is based on other sources of information such as experimental studies in animals, or prediction based on corrosivity (to skin/eyes). 
4. For mixtures, the health effect data required for classification and labelling may be obtained by the application of test methods indicated above. Classification may also be obtained by application of methods indicated in Part B of Directive 1999/45/EC ('The Preparations Directive'), 'Concentration limits to be used in evaluation of health hazards'. This sets out specific concentration limits for gaseous and nongaseous mixtures (or preparations). In short, a mixture may be classified as 'R37, Irritating to the Respiratory Tract' if that mixture contains more than a specified percentage concentration of a substance that has been classified as 'Corrosive' (see Appendix 2).

\section{The US System}

5. In the USA, there is no classification specifically for this endpoint; it is handled as a target organ effect, based mainly upon human experience. In the USA, for the Occupational Safety and Health Administration (OSHA) and Consumer Product Safety Commission (CPSC), target organ effects lead to identification of the specific organ on the label. The various precautionary statements and statements of treatment can be organized in a specific manner. Hence, respiratory tract irritation is covered in this manner.

\section{The Canadian System}

6. The Canadian Workplace Hazardous Materials Information System (WHMIS) includes provisions for "chronic toxic effects". A chronic toxic effect is defined as an adverse effect on the health of a person or test animal that develops over time, following a single exposure to a toxic substance, or after prolonged or repeated exposure to a toxic substance under conditions that do not produce the same effect from a single exposure. Adverse health effects in this category include life-threatening or serious impairment of body organs and the cardiovascular or nervous system. Respiratory tract irritation would fall into this hazard class.

The criteria for substances or tested mixtures for this hazard class are detailed in Appendix 3.

\section{UN Transport of Dangerous Goods}

7. In the UN transport regulations irritation of the respiratory system (RTI) is covered indirectly via the subsidiary corrosive risk for toxic gases. Toxic gases are:

Gases

- which are known to be so toxic or corrosive to humans as to pose a hazard to health; or

- which are presumed to be toxic or corrosive to humans because they have an $\mathrm{LC}_{50}$ value equal to or less than $5,000 \mathrm{ml} / \mathrm{m}^{3}(\mathrm{ppm})$.

Gases meeting the above criteria owing to their corrosivity are to be classified as toxic with a subsidiary corrosive risk.

Mixtures of gases:

A gas mixture has a subsidiary risk of corrosivity when the mixture is known by human experience to be destructive to the skin, eyes or mucous membranes or when the $\mathrm{LC}_{50}$ value of the corrosive components of the mixture is equal to or less than $5,000 \mathrm{ml} / \mathrm{m}^{3}(\mathrm{ppm})$ when the $\mathrm{LC}_{50}$ is calculated by a formula using mol fractions and $\mathrm{LC}_{50}$ values. 


\section{APPENDIX 1: DEVELOPMENT OF R37, IRRITATING TO THE RESPIRATORY SYSTEM}

Within the EU, the first general definition of "irritating" in Directive 67/548/EEC (27 June 1967) was recorded as "Non-corrosive substances and preparations which, through immediate, prolonged or repeated contact with the skin or mucous membrane, may cause inflammation". The respective R-(isk) phrase was initially R84 = Irritating to skin, eyes and respiratory system.

Directive 76/907 (14 July 1976): Creation of new (separate) R phrase: R37 = Irritating to respiratory system.

Directive 83/467 (16 Sept. 1983): For the first time a criterion was introduced: "Substances and preparations which cause serious irritation to the respiratory system, based normally on practical observation." This means that at that time data from animal experiments were not regarded to be useful in classification for this endpoint.

Directive 93/21/EEC (27 April 1993): R37 is slightly modified. New criteria: "Substances and preparations which cause serious irritation to the respiratory system, based normally on practical observation in humans".

\section{Directive 96/54/EEC (30 July 1996):}

Positive results from appropriate animal tests were for the first time introduced. Thus, test results in inhalation toxicity studies including histopathological investigations can be used for classifying purposes.

New expanded criteria were established in order to discriminate classification between respiratory irritation and $\mathrm{R} 48=$ Danger of serious damage to health by prolonged exposure.

Furthermore, the Alarie test was introduced as a basis for respiratory irritation.

The revised criteria, which are valid up to now are (as laid out in EU guidance documents):

\section{'R 37: Irritating to respiratory system}

Is assigned to substances and preparations which cause serious irritation to the respiratory system based on:

- practical observation in humans

- positive results from appropriate animal tests

Comments regarding the use of R37:

In interpreting practical observations in humans, care should be taken to distinguish between effects which lead to classification with R48 (see section 3.2.4.) from those leading to classification with R37. Conditions normally leading to classification with R37 are reversible and usually limited to the upper airways.

Positive results from appropriate animal tests may include data obtained in a general toxicity test, including histopathological data from the respiratory system. Data from the measurement of experimental bradypnea may also be used to assess airway irritation.' 


\section{APPENDIX 2: CLASSIFICATION OF MIXTURES (PREPARATIONS) WITHIN THE EU}

(Taken from Directive 1999/45/EC of the European Parliament and of the Council, published in the Official Journal of the European Communities, 30/7/1999)

Non-gaseous mixtures:

\begin{tabular}{|c|c|c|c|c|}
\hline \multirow{2}{*}{$\begin{array}{c}\text { Classification } \\
\text { of the } \\
\text { substance }\end{array}$} & \multicolumn{4}{|c|}{ Classification of the mixture (preparation) } \\
\hline & C with R35 & C with R34 & Xi with R41 & Xi with R36, R37, R38 \\
\hline C with R35 & $\begin{array}{c}\text { Concentration } \\
\geq 10 \% \\
\text { R35 } \\
\text { obligatory }\end{array}$ & $\begin{array}{c}5 \% \leq \\
\text { concentration } \\
<10 \% \\
\text { R34 } \\
\text { obligatory }\end{array}$ & $5 \%(*)$ & $\begin{array}{c}1 \% \leq \text { concentration }< \\
5 \% \\
\text { R36/38 obligatory }\end{array}$ \\
\hline C with R34 & & $\begin{array}{c}\text { Concentration } \\
\geq 10 \% \\
\text { R34 } \\
\text { obligatory }\end{array}$ & $10 \%(*)$ & $\begin{array}{c}5 \% \leq \text { concentration }< \\
10 \% \\
\text { R36/38 obligatory }\end{array}$ \\
\hline
\end{tabular}

\begin{tabular}{|c|c|c|c|c|}
\hline \multirow{2}{*}{$\begin{array}{c}\text { Classification } \\
\text { of the } \\
\text { substance }\end{array}$} & \multicolumn{3}{|c|}{ Classification of the mixture (preparation) } \\
\cline { 2 - 5 } & C with R35 & C with R34 & Xi with R41 & Xi with R36, R37, R38 \\
\hline C with R41 & & $\begin{array}{c}\text { Concentration } \\
\geq 10 \% \\
\text { R41 obligatory }\end{array}$ & $\begin{array}{c}5 \% \leq \text { concentration < } \\
10 \% \\
\text { R36 obligatory }\end{array}$ \\
\hline $\begin{array}{c}\text { C with R36, } \\
\text { R37, R38 }\end{array}$ & & & $\begin{array}{c}\text { concentration } \geq 20 \% \\
\text { R36, R37, R38 are } \\
\text { obligatory in the light } \\
\text { of the concentration } \\
\text { present if they apply to } \\
\text { the substances under } \\
\text { consideration }\end{array}$ \\
& & & \\
& & & \\
& & & \\
\end{tabular}

(*) According to the labelling guide (Annex VI to Directive 67/548/EEC), corrosive substances assigned risk phrases R35 or R34 must also be considered as being assigned phrase R41. Consequently, if the preparation contains corrosive substances with R35 or R34 below the concentration limits for a classification of the preparation as corrosive, such substances can contribute to a classification of the preparation as irritant with $R 41$ or irritant with $R 36$. 
Gaseous mixtures:

\begin{tabular}{|c|c|c|c|c|}
\hline \multirow{2}{*}{$\begin{array}{l}\text { Classification } \\
\text { of the } \\
\text { substance } \\
\text { (gas) }\end{array}$} & \multicolumn{4}{|c|}{ Classification of the gaseous mixture (preparation) } \\
\hline & C with R35 & C with R34 & Xi with R41 & $\begin{array}{c}\text { Xi with R36, } \\
\text { R37, R38 }\end{array}$ \\
\hline C with R35 & $\begin{array}{c}\text { Concentration } \\
\geq 1 \% \\
\text { R35 } \\
\text { obligatory }\end{array}$ & $\begin{array}{c}0.2 \% \leq \\
\text { concentration } \\
<1 \% \\
\text { R34 } \\
\text { obligatory }\end{array}$ & $0.2 \%(*)$ & $\begin{array}{c}0.02 \% \leq \\
\text { concentration } \\
<0.2 \% \\
\text { R36/37/38 } \\
\text { obligatory }\end{array}$ \\
\hline C with R35 & & $\begin{array}{c}\text { concentration } \\
\geq 5 \% \\
\text { R34 } \\
\text { obligatory }\end{array}$ & $5 \%(*)$ & $\begin{array}{c}0.5 \% \leq \\
\text { concentration } \\
<5 \% \\
\text { R36/37/38 } \\
\text { obligatory }\end{array}$ \\
\hline C with R41 & & & $\begin{array}{c}\text { Concentration } \\
\geq 5 \% \\
\text { R41 } \\
\text { obligatory }\end{array}$ & $\begin{array}{c}0.5 \% \leq \\
\text { concentration } \\
<5 \% \\
\text { R36 } \\
\text { obligatory }\end{array}$ \\
\hline $\begin{array}{c}\text { Xi with R36, } \\
\text { R37, R38 }\end{array}$ & & & & $\begin{array}{c}\text { concentration } \\
\geq 5 \% \\
\text { R36, R37, } \\
\text { R38 } \\
\text { obligatory as } \\
\text { appropriate }\end{array}$ \\
\hline
\end{tabular}

(*) According to the labelling guide (Annex VI to Directive 67/548/EEC), corrosive substances assigned risk phrases R35 or R34 must also be considered as being assigned phrase R41. Consequently, if the preparation contains corrosive substances with R35 or R34 below the concentration limits for a classification of the preparation as corrosive, such substances can contribute to a classification of the preparation as irritant with $R 41$ or irritant with $R 36$. 


\section{Appendix 3}

Canadian Workplace Hazardous Materials Information System

\begin{tabular}{|c|c|c|}
\hline Basis for Evaluation & "Very Toxic Material" & "Toxic Material" \\
\hline $\begin{array}{l}\text { ORAL ROUTE OF EXPOSURE } \\
\text { 1. Subchronic Oral Toxicity } \\
\text { - Rodent OECD Test } \\
\text { Guideline 408 } \\
\text { 2. Subchronic Oral Toxicity } \\
\text { - Non-Rodent OECD Test } \\
\text { Guideline 409 } \\
\text { 3. } \text { Oral Route Test } \\
\text { - OECD Test Guideline } \\
\text { 452 }\end{array}$ & $\begin{array}{l}\text { Dose of not more than } 10 \mathrm{mg} \text { per } \mathrm{kg} \\
\text { of weight of test animal per day }\end{array}$ & $\begin{array}{l}\text { Dose of more than } 10 \mathrm{but} \text { not } \\
\text { more than } 100 \mathrm{mg} \text { per } \mathrm{kg} \text { of } \\
\text { weight of test animal per day }\end{array}$ \\
\hline $\begin{array}{ll}\text { DERMAL ROUTE OF } \\
\\
\text { EXPOSURE } \\
\text { 1. } \\
\text { Subchronic Dermal } \\
\text { Toxicity } \\
\text { - OECD Test Guideline } \\
411 \\
\text { 2. } \\
\text { Dermal Route Test } \\
\text { - OECD Test Guideline } \\
452\end{array}$ & $\begin{array}{l}\text { Dose of not more than } 20 \mathrm{mg} \text { per } \mathrm{kg} \\
\text { of weight of test animal per day }\end{array}$ & $\begin{array}{l}\text { Dose of more than } 20 \text { but not } \\
\text { more than } 200 \mathrm{mg} \text { per kg of } \\
\text { weight of test animal per day }\end{array}$ \\
\hline $\begin{array}{l}\text { INHALATION ROUTE OF } \\
\text { EXPOSURE } \\
\text { 1. Subchronic Inhalation } \\
\text { Toxicity } \\
\text {-OECD Test Guideline } \\
408 \\
\text { 2. Inhalation Route Test } \\
\text { - OECD Test Guideline } \\
\text { 452 }\end{array}$ & $\begin{array}{l}\text { Concentration of not more than } 25 \\
\text { ppm by volume of a gas or vapour, } \\
\text { or not more than } 10 \mathrm{mg} / \mathrm{m}^{3} \text { of a dust, } \\
\text { mist or fume. }\end{array}$ & $\begin{array}{l}\text { Concentration of more than } \\
25 \mathrm{ppm} \text { but not more than } \\
250 \mathrm{ppm} \text { by volume of a gas } \\
\text { or vapour, or more than } 10 \\
\mathrm{mg} / \mathrm{m}^{3} \text { but not more than } 100 \\
\mathrm{mg} / \mathrm{m}^{3} \text { of a dust, mist or } \\
\text { fume. }\end{array}$ \\
\hline
\end{tabular}

